\title{
Transmission rate variation among three $B$ chromosome variants in the fish Prochilodus lineatus (Characiformes, Prochilodontidae)
}

\author{
MANOLO PENITENTE ${ }^{1}$, TATIANA A. VOLTOLIN ${ }^{1}$, JOSÉ A. SENHORINI ${ }^{2}$, \\ JEHUD BORTOLOZZI ${ }^{1}$, FAUSTO FORESTI $^{3}$ and FÁBIO PORTO-FORESTI ${ }^{1}$ \\ ${ }^{1}$ Laboratório de Genética de Peixes, Universidade Estadual Paulista, \\ Av. Eng. Luiz Edmundo Carrijo Coube, 1401, Vargem Limpa, 17033-360 Bauru, SP, Brasil \\ ${ }^{2}$ Laboratório de Genética e Reprodução de Peixes, Instituto Chico Mendes de Conservação da Biodiversidade/ICMBio, \\ Centro Nacional de Pesquisa e Conservação de Peixes Continentais/CEPTA, \\ Rodovia SP 201, Km 6,5, 13630-970 Pirassununga, SP, Brasil \\ ${ }^{3}$ Laboratório de Biologia e Genética de Peixes, Universidade Estadual Paulista, \\ Distrito de Rubião Júnior, s/n, 18618-970 Botucatu, SP, Brasil \\ Manuscript received on October 27, 2011; accepted for publication on October 5, 2012

\begin{abstract}
Cytogenetic studies were developed in Prochilodus lineatus (Valenciennes 1836), describing an interesting system of small supernumerary chromosomes. The purpose of this work is to study the frequency and morphology of B chromosomes in individuals from the parental line and the inheritance patterns of these elements in individuals obtained from controlled crosses in the species $P$. lineatus. The transmission rate of $\mathrm{B}$ chromosomes revealed a $\mathrm{k}_{\mathrm{B}}=0.388$ for the acrocentric type, a $\mathrm{kB}=0.507$ for the metacentric type and a $k_{B}=0.526$ for the submetacentric type. The obtained results raise hypothesis that B-acrocentric chromosomes are involved in an extinction process in this species, while the metacentric and submetacentric supernumerary elements comprises a neutral mechanism and follows a Mendelian transmission rate.
\end{abstract}

Key words: supernumerary chromosomes, controlled crosses, curimbatá, cytogenetic, inheritance.

\section{INTRODUCTION}

B chromosomes are widely distributed among eukaryotes and their occurrence has been reported in ten species of fungi, nearly 1,300 plants, and over 500 animals (Camacho 2005). In addition, $\mathrm{B}$ chromosomes have been described to date in 38 species of Neotropical fish (Oliveira et al. 2009). These structural elements have been identified in diverse karyotypes, but intriguing questions still persist about their structure, function or behavior.

Correspondence to: Fabio Porto-Foresti

E-mail: fpforesti@fc.unesp.br
The first evidence of $\mathrm{B}$ chromosomes in Neotropical fishes was identified in Prochilodus lineatus (Pauls and Bertollo 1983). This species presents a diploid number of 54 chromosomes of the metacentric and submetacentric types, with a fundamental number of 108 (Pauls and Bertollo 1983, 1990, Oliveira et al. 1997, Cavallaro et al. 2000, Jesus and Moreira-Filho 2003, Artoni et al. 2006, Voltolin et al. 2009). Cytogenetic studies of individuals of $P$. lineatus captured at different locations revealed a numerical variation of supernumerary chromosomes in all populations analyzed, and the number of extra-chromosomes 
always ranged from zero to seven (Pauls and Bertollo 1983, Oliveira et al. 1997, Cavallaro et al. 2000, Jesus et al. 2003). However, Voltolin et al. (2011) recently detected the presence of eight and nine supernumerary chromosomes in individuals of this species resulting from induced crossings.

Supernumerary chromosomes exhibit a remarkable variation in size and morphology among fish, i.e., the occurrence of large genomic elements as macrochromosomes was described in species of the genus Astyanax (Maistro et al. 1992, Salvador and Moreira-Filho 1992, Vicente et al. 1996, Moreira-Filho et al. 2001, Ferro et al. 2003, Hashimoto et al. 2008); of medium size in Rhamdia (Fenocchio and Bertollo 1990, Fenocchio et al. 2000); and also as small elements identified as microchromosomes in Prochilodus (Pauls and Bertollo 1983, 1990, Venere et al. 1999, Cavallaro et al. 2000, Oliveira et al. 2003, Voltolin et al. 2009). Artoni et al. (2006), studying specimens of P. lineatus from the Mogi-Guaçu River, observed the presence of three types of supernumerary microchromosomes in this species, which were classified as B-acrocentric, B-metacentric, and B-submetacentric.

A mechanism of genetic control in the transmission patterns of these extra elements has been demonstrated in some animals, including the grasshopper Myrmeleotettix maculatus (Shaw and Hewitt 1985, Shaw et al. 1985), the mealy bug Pseudococus affinis (Nur and Brett 1987, 1988), the grasshopper Eyprepocnemis plorans (Herrera et al. 1996) and also in some plants including Hypochoeris maculata (Parker et al. 1982), Aegilops speltoides (Cebriá et al. 1994), and Allium schoenoprassum (Bougourd and Plowman 1996).

The knowledge about the inheritance of supernumerary chromosomes in fish carriers is still scarce in the literature. The process was identified in fish for the first time in Poecilia formosa (Schartl et al. 1995). Later, Oliveira et al. (1997) and Voltolin et al. (2010) conducted studies on the inheritance of B chromosomes in P. lineatus and found that the transmission pattern of these chromosomes follows a regular expected meiotic behavior in individuals of both sexes, showing a Mendelian rate. Different models are proposed to explain the presence, accumulation and possible effects of B chromosomes in the organisms (White 1973), as well as the parasitic model (Östergren 1945, Nur 1966a, b, 1977), or the selfish model (Jones 1985, Shaw and Hewitt 1990).

The present study performed a thorough analysis of the transmission pattern of three different types of B chromosomes found in $P$. lineatus, through controlled crosses, establishing relations on the dynamics, maintenance and transmission of the microchromosomes found in this species, in order to better understanding the processes involved in the inheritance of these genomic elements.

\section{MATERIALS AND METHODS}

Two groups of Prochilodus lineatus were cytogenetically analyzed. The first was composed of 50 samples from the natural population of the Mogi-Guaçu River, Pirassununga, São Paulo, Brazil, used as parental generation. The second group involved in controlled crossings, so that six males and six females of the parental generation were selected to form eight couples through the combination of gametes (Fig. 1). The controlled crosses were performed at the Centro de Pesquisa e Gestão dos Recursos Pesqueiros Continentais/ Instituto Chico Mendes de Conservação da Biodiversidade, CEPTA/ICMBio, Pirassununga, São Paulo, Brazil. The second group was composed of 113 individuals obtained from eight crosses representing the filial generation.

The chromosome preparations of the parental generation were obtained from a lymphocyte culture following the method used by Fenocchio and Bertollo (1988). The chromosome preparations of individuals in the filial generation were obtained from kidney fragments according to the protocol 


\begin{tabular}{|c|c|c|c|c|c|}
\hline \multicolumn{3}{|c|}{ COUPLE 1} & \multicolumn{3}{|c|}{ COUPLE 2} \\
\hline Male 1 & $x$ & Female 1 & Male 2 & $x$ & Female 2 \\
\hline $2 \mathrm{~B}(1 \mathrm{~m} / 1 \mathrm{sm})$ & & $2 \mathrm{~B}(1 \mathrm{a} / 1 \mathrm{~m})$ & $3 \mathrm{~B}(1 \mathrm{a} / 2 \mathrm{sm})$ & & $3 B(1 \mathrm{a} / 2 \mathrm{~m})$ \\
\hline \multicolumn{3}{|c|}{ COUPLE 3} & \multicolumn{3}{|c|}{ COUPLE 4} \\
\hline Male 3 & $x$ & Female 3 & Male 4 & $x$ & Female 4 \\
\hline $4 \mathrm{~B}(1 \mathrm{a} / 1 \mathrm{~m} / 2 \mathrm{sm}$ & & $3 \mathrm{~B}(1 \mathrm{~m} / 2 \mathrm{sm})$ & $5 \mathrm{~B}(3 \mathrm{~m} / 2 \mathrm{sm})$ & & $5 B(4 \mathrm{~m} / 1 \mathrm{sm})$ \\
\hline \multicolumn{3}{|c|}{ COUPLE 5} & \multicolumn{3}{|c|}{ COUPLE 6} \\
\hline Male 4 & $x$ & Female 3 & Male 5 & $x$ & Female 5 \\
\hline $5 \mathrm{~B}(3 \mathrm{~m} / 2 \mathrm{sm})$ & & $3 B(1 \mathrm{~m} / 2 \mathrm{sm})$ & $6 \mathrm{~B}(3 \mathrm{~m} / 3 \mathrm{sm})$ & & $5 B(4 \mathrm{~m} / 1 \mathrm{sm})$ \\
\hline \multicolumn{3}{|c|}{ COUPLE 7} & \multicolumn{3}{|c|}{ COUPLE 8} \\
\hline Male 6 & $x$ & Female 6 & Male 5 & $x$ & Female 3 \\
\hline $1 \mathrm{~B}(1 \mathrm{~m})$ & & $3 \mathrm{~B}(2 \mathrm{~m} / 1 \mathrm{sm})$ & $6 \mathrm{~B}(3 \mathrm{~m} / 3 \mathrm{sm})$ & & $3 B(1 \mathrm{~m} / 2 \mathrm{sm})$ \\
\hline
\end{tabular}

Fig. 1 - Controlled crosses involving Prochilodus lineatus individuals with different numbers of supernumerary chromosomes indicated in association of sex in individuals of parental lines. m: B-metacentric, sm: B-submetacentric, a: B-acrocentric.

followed by Foresti et al. (1981). All representatives of the parental generation were marked with magnetic tags and cytogenetically identified according to the number and type of supernumerary chromosomes to enable the achievement of controlled crossings.

The chromosome morphology was determined according to the ratio of arms established by Levan et al. (1964), and the chromosomes were classified as metacentric (m), submetacentric (sm) and acrocentric (a) and arranged in descending order of size.

For the determination of $\mathrm{B}$ chromosome modal numbers, 30 well spread metaphase cells per individual were analyzed. The transmission rate of $\mathrm{B}$ chromosomes $(\mathrm{kB})$ was calculated from the mean number of $\mathrm{B}$ chromosomes in the progeny, divided by the total number of parental Bs, according to López-León et al. (1992).

\section{RESULTS}

The basic sample analyzed comprised 50 specimens of Prochilodus lineatus collected from the natural population of the Mogi-Guaçu River, having up to six B chromosomes in their somatic cells. There was no intraindividual variation in natural population and in the whole filial generation. The frequency of supernumerary chromosomes found on this natural population was $6.34 \%$ of B-acrocentric, $53.18 \%$ of B-metacentric, and $40.48 \%$ of B-submetacentric (Fig. 2). These data show a predominance of B-metacentric and $\mathrm{B}$-submetacentric types in the natural population of curimbatá from the Mogi-Guaçu River. In addition, we analyzed 113 individuals from the filial generation (F1), obtained from eight controlled crosses. The B-acrocentric type was present in the parental generation in individuals of only three crossings, confirming the low frequency found in the natural population of the Mogi-Guaçu River, whilst B-metacentric and B-submetacentric were involved in all crosses.

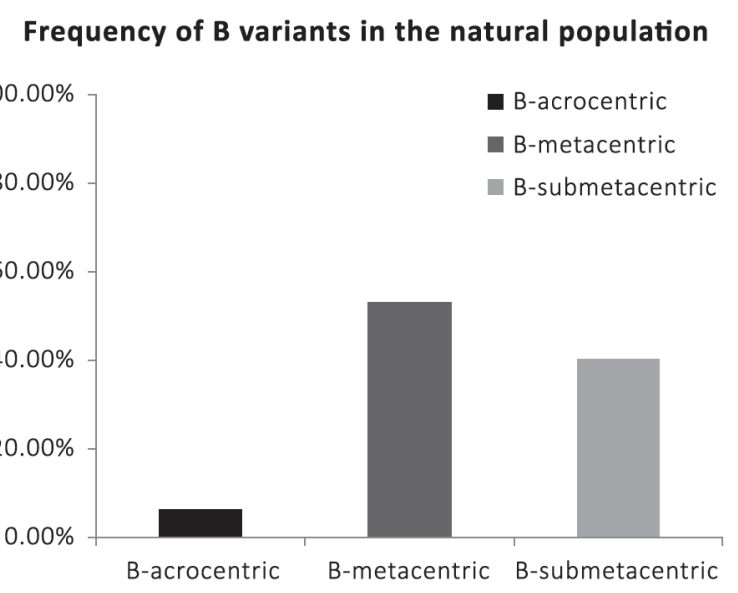

Fig. 2 - Frequency of different types of B chromosomes found in specimens of Prochilodus lineatus in the natural population of Mogi-Guaçu River. The B-acrocentric showed the lowest incidence $(6.34 \%)$ while the B-metacentric presented $53.18 \%$ and the B-submetacentric presented $40.48 \%$.

The analysis of the filial generation showed that B-acrocentric type was less frequent than B-metacentric and B-submetacentric types in the whole F1 generation in controlled crosses (Table I). Furthermore, it was possible to calculate the average of transmission rate $\left(\mathrm{k}_{\mathrm{B}}\right)$ of each morphological type of $\mathrm{B}$ chromosome to investigate the transmission pattern of the three variants of supernumeraries, 
TABLE I

Frequency of each supernumerary chromosome variant on filial generation in controlled crosses.

\begin{tabular}{|c|c|c|c|c|c|c|}
\hline Couples & $\hat{\sigma}$ & q & $\mathbf{n}$ & $f_{a}$ & $\mathbf{f}_{\mathrm{m}}$ & $\mathbf{f}_{\mathrm{sm}}$ \\
\hline Couple 1 & $2 \mathrm{~B}(1 \mathrm{~m} / 1 \mathrm{sm})$ & $2 \mathrm{~B}(1 \mathrm{a} / 1 \mathrm{~m})$ & 14 & $5(16.6 \%)$ & $17(56.7 \%)$ & $8(26.7 \%)$ \\
\hline Couple 2 & $3 \mathrm{~B}(1 \mathrm{a} / 2 \mathrm{sm})$ & $3 \mathrm{~B}(1 \mathrm{a} / 2 \mathrm{~m})$ & 14 & $10(25.0 \%)$ & $15(37.5 \%)$ & $15(37.5 \%)$ \\
\hline Couple 3 & $4 \mathrm{~B}(1 \mathrm{a} / 1 \mathrm{~m} / 2 \mathrm{sm})$ & $3 \mathrm{~B}(1 \mathrm{~m} / 2 \mathrm{sm})$ & 20 & $9(14.5 \%)$ & $23(37.0 \%)$ & $30(48.5 \%)$ \\
\hline Couple 4 & $5 \mathrm{~B}(3 \mathrm{~m} / 2 \mathrm{sm})$ & $5 \mathrm{~B}(4 \mathrm{~m} / 1 \mathrm{sm})$ & 12 & ------ & $35(59.3 \%)$ & $24(40.7 \%)$ \\
\hline Couple 5 & $5 \mathrm{~B}(3 \mathrm{~m} / 2 \mathrm{sm})$ & $3 \mathrm{~B}(1 \mathrm{~m} / 2 \mathrm{sm})$ & 15 & ------ & $27(47.3 \%)$ & $30(52.7 \%)$ \\
\hline Couple 6 & $6 \mathrm{~B}(3 \mathrm{~m} / 3 \mathrm{sm})$ & $5 \mathrm{~B}(4 \mathrm{~m} / 1 \mathrm{sm})$ & 17 & ------ & $59(63.4 \%)$ & $34(36.6 \%)$ \\
\hline Couple 7 & $1 \mathrm{~B}(1 \mathrm{~m})$ & $3 \mathrm{~B}(2 \mathrm{~m} / 1 \mathrm{sm})$ & 10 & ------ & $16(76.2 \%)$ & $5(23.8 \%)$ \\
\hline Couple 8 & $6 \mathrm{~B}(3 \mathrm{~m} / 3 \mathrm{sm})$ & $3 \mathrm{~B}(1 / 2 \mathrm{sm})$ & 11 & ------ & $17(38.6 \%)$ & $27(61.4 \%)$ \\
\hline
\end{tabular}

$\mathrm{n}$ : total of individuals analyzed in the filial generation, a: number of B-acrocentric found on parents, m: number of B-metacentric, $\mathrm{sm}$ : number of B-submetacentric, $\mathrm{f}_{\mathrm{a}}$ : frequency of the B-acrocentric in offspring, $\mathrm{f}_{\mathrm{m}}$ : frequency of the $\mathrm{B}$-metacentric, $\mathrm{f}_{\mathrm{sm}}$ : frequency of the B-submetacentric.

where the types B-acrocentric, B-metacentric, and B-submetacentric presented respectively the following mean values: $\mathrm{k}_{\mathrm{Ba}}=0.388, \mathrm{k}_{\mathrm{Bm}}=0.507$ and $\mathrm{k}_{\mathrm{Bsm}}=0.526$ (Fig. 3). B-acrocentric type presented the lowest average transmission rate.

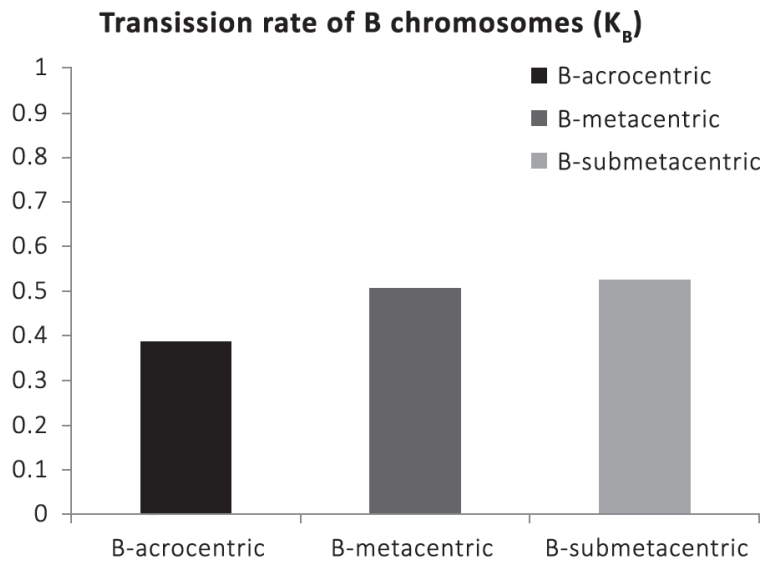

Fig. 3 - Average transmission rate $\left(\mathrm{k}_{\mathrm{B}}\right)$ of $\mathrm{B}$ chromosome types in offspring of Prochilodus lineatus resulting from controlled crosses. The value of $\mathrm{k}_{\mathrm{B}}$ was 0.388 for the $\mathrm{B}$-acrocentric, 0.507 for the B-metacentric, and 0.526 for the B-submetacentric.

\section{DISCUSSION}

Studies performed on the inheritance patterns of supernumerary chromosomes in the specie P. lineatus by Oliveira et al. (1997) and Voltolin et al. (2010) reported that the transmission of microchromosomes was consistent with the Mendelian rate $\left(\mathrm{k}_{\mathrm{B}}=0.500\right)$.
These data describe only the numerical frequency variation of microchromosomes B in Prochilodus. However, Artoni et al. (2006), studying specimens of $P$. lineatus from the Mogi-Guaçu River, revealed the presence of three morphological variants of supernumerary microchromosomes in this species that were classified as B-acrocentric, B-metacentric and B-submetacentric, but no information about the frequency of the different types was included in the results.

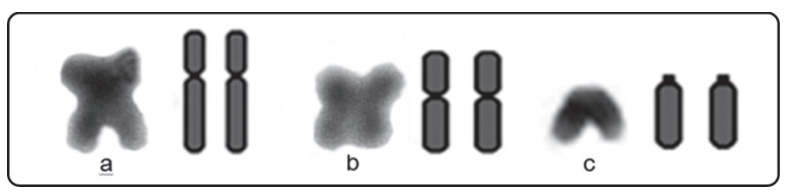

Fig. 4 - Types and relative size of supernumerary chromosomes found in Prochilodus lineatus. (a) submetacentric; (b) metacentric; and (c) acrocentric.

Cytogenetic analysis performed in the present study confirmed that there is no intraindividual variation of $\mathrm{B}$ chromosomes in natural population and in the F1 generation, these results are consistent with those by Oliveira et al. (1997), Cavallaro et al. (2000) and Voltolin et al. (2010). Furthermore, we found the three types of $\mathrm{B}$ microchromosomes in individuals of the parental line, collected directly in the natural population, in a similar result as described by Artoni et al. (2006) (Fig. 4), but it was observed that B-metacentric and B-submetacentric 
types were more frequent than B-acrocentric type (Fig. 2). The low frequency of B-acrocentric chromosomes was observed both in individuals from the natural population of the Mogi-Guaçu River and in individuals produced by induced crossings involving the parental line sample. So it may be noted that similar frequency patterns for the three types of extra chromosomes can be found in nature and in captive conditions, and the data points to the fact that $\mathrm{B}$-acrocentric chromosome may have a lower transmission rate when compared to the other two types of B in this species.

The prevalence of B-metacentric over the $\mathrm{B}$-acrocentric type in the transmission inheritance patterns was also identified by Araújo et al. (2002) in populations of the wasp Trypoxylon albitarse. The authors affirmed that the B-metacentric chromosome showed a higher efficiency of transmission in relation to the acrocentric type. However, the few studies involving the inheritance of morphological types of supernumerary in fish permitted only to correlate the low frequency of B-acrocentric found both in natural and captive populations of $P$. lineatus to transmission efficiency.

TABLE II

Relationship between the $k_{B}$ with frequency of the supernumerary chromosomes variants.

\begin{tabular}{cccc}
\hline B variant & $\mathbf{F}$ & $\mathbf{F} \%$ & $\mathbf{K}_{\mathbf{B}}$ \\
\hline acrocentric & 8 & $6.34 \%$ & 0.388 \\
metacentric & 67 & $53.18 \%$ & 0.507 \\
submetacentric & 51 & $40.48 \%$ & 0.526 \\
\hline
\end{tabular}

$\mathrm{k}_{\mathrm{B}}$ : transmission rate of $\mathrm{B}$ chromosomes, f: numeric frequency, $\mathrm{f} \%$ : percentage frequency.

The results obtained in the present work demonstrate the emergence of an intrinsic relationship between the frequency of each type of extra chromosome with its respective supernumerary transmission rate $\left(\mathrm{k}_{\mathrm{B}}\right)$, where the B-acrocentric type showed a transmission rate lower than the number existing in the parental generation $\left(\mathrm{k}_{\mathrm{B}}=0.388\right)$, leading automatically to a lower incidence of the filial generation (Table I), and in a similarly way to the low frequency observed in the natural population (Fig. 2). The B-metacentric $\left(\mathrm{k}_{\mathrm{B}}=0.507\right)$ and $\mathrm{B}$-submetacentric $\left(\mathrm{k}_{\mathrm{B}}=0.526\right)$ types show a Mendelian rate $\left(\mathrm{k}_{\mathrm{B}}=0.500\right)$, which exhibits neutralization stage, and are more frequent in the natural population $(53.18 \%$ and $40.48 \%$, respectively). However, the transmission rate of the B-acrocentric type indicates the occurrence of an imminent decline process that may result in the extinction of this morphological type in the population of the Mogi-Guaçu River, if no structural modification occurs in their chromosome structure, as proposed by Camacho et al. (2000).

The hypothesis proposed by Araújo et al. (2002) that B-acrocentric chromosomes have by themselves a lower transmission rate when compared to the two other supernumeraries cannot be discarded. Concerning the Mendelian rate the B-meta and submetacentric types are in a neutral stage and can mutate along the evolutionary process to remain in the genome of this species. Based on these two hypotheses, which can guarantee the maintenance of different types of B in the genome of $P$. lineatus, it is possible to propose that the metacentric and submetacentric B chromosomes types have a higher transmission rate.

Therefore, new population surveys on the frequency of the different types of B chromosomes found in the natural population of the Mogi-Guaçu River, as well as a greater number of controlled crosses involving also individuals non-carriers of supernumeraries, associated with further studies about the meiotic behavior of these genomic elements in this species are necessary for a better understanding of the dynamics and inheritance of B chromosomes in P. lineatus from the Mogi-Guaçu River.

\section{ACKNOWLEDGMENTS}

The authors are grateful to R. Devidé for his technical assistance. Funds supporting this study were provided by Fundação de Amparo à Pesquisa 
do Estado de São Paulo (FAPESP), Coordenação de Aperfeiçoamento de Pessoal de Nível Superior (CAPES) and Centro de Pesquisa e Gestão de Recursos Pesqueiros Continentais/Instituto Chico Mendes de Conservação da Biodiversidade (CEPTA/ICMBio).

\section{RESUMO}

Estudos citogenéticos foram desenvolvidos em Prochilodus lineatus (Valenciennes 1836), os quais descrevem um interessante sistema de pequenos cromossomos supranumerários. O objetivo deste trabalho foi estudar a frequência e morfologia dos cromossomos B em indivíduos a partir da linhagem parental e os padrões de herança destes elementos em indivíduos obtidos a partir de cruzamentos controlados na espécie $P$. lineatus. A taxa de transmissão dos cromossomos B revelaram um $\mathrm{k}_{\mathrm{B}}=0,388$ para o tipo acrocêntrico, $\mathrm{k}_{\mathrm{B}}=0,507$ para o tipo metacêntrico e $\mathrm{k}_{\mathrm{B}}=0,526$ submetacêntrico. Os resultados obtidos levantam hipóteses de que os cromossomos B do tipo acrocêntrico se encontram em fase de extinção, enquanto que os supranumerários do tipo metacêntrico e submetacêntrico encontram-se em fase de neutralização, seguindo uma taxa de transmissão Mendeliana.

Palavras-chave: cromossomos supranumerários, cruzamentos controlados, curimbatá, citogenética, herança.

\section{REFERENCES}

Araújo SMSR, Pompolo SG, Perfectti F and Camacho JPM. 2002. Integration of a B chromosome into the A genome of a wasp, revisited. R Soc Lond 269: 1475-1478.

ARTONI RF, VicARI MR, ENDLER AL, CAVALlaro ZI, JESUS CM, Almeida MC, Moreira-Filho O AND Bertollo LAC. 2006. Banding pattern of and B chromosome of Prochilodus lineatus (Characiformes, Prochilodontidae), with comments on B chromosome evolution. Gen Mol Biol 127: 277-284.

Bougourd SM AND Plowman AB. 1996. The inheritance of chromosome in Allium schoenoprassum L. Chrom Res 4: 151-158.

Camacho JPM, Sharbel TF and Beukboom LW. 2000 B-chromosome evolution. Phil Trans R Soc Lond 355: 163-178.

CAMACHO JPM. 2005. B chromosomes. In: Gregory TR (Ed), The evolution of the Genome. Elsevier, San Diego, p. 223-286.
Cavallaro ZI, Bertollo LaC, Perfectti F and CAMacho JPM. 2000. Frequency increase and mitotic stabilization of a B chromosome in fish Prochilodus lineatus. Chrom Res 8: 627-634.

Cebriá A, Navarro ML and Puertas MJ. 1994. Genetic control of B chromosome transmission in Aegilops speltoides (Poaceae). Am J Bot 81: 1502-1507.

FenOCCHIO AS AND BerTollo LAC. 1988. A simple method for fresh-water fish lymphocyte culture. Rev Brasil Genet 11(4): 847-852.

FENOCCHIO AS AND BerTollo LAC. 1990. Supranumerary chromosome in a Rhamdia hilarii population (Pisces, Pimelodidae). Genetica 81: 193-198.

FENOCCHIO AS, BERTOLlO LAC, TAKAHASHI CS AND CAMACHO JPM. 2000. B chromosomes in two fish species, genus Rhamdia (Siluriformes, Pimelodidae). Folia Biol 48: 105-109.

FERro DAM, MoreirA-Filho O AND Bertollo LAC. 2003. B chromosome polymorphism in the fish, Astyanax scabripinnis. Genetica 119: 147-153.

Foresti F, AlmEIDA-TOLEDo LF AND TOLEDO-FILHO SA. 1981. Polymorfic nature of nucleous organizer regions in fishes. Cytogenet Cell Genet 31: 137-144.

Hashimoto DT, Gonçalves VR, Bortolozzi J, Foresti F AND PORTO-Foresti F. 2008. First report of a B chromosome in population of the Astyanax scabripinnis (Characiformes, Characidae). Gen Mol Biol 31: 275-278.

Herrera JA, López-León MD, CABrero J, SHAW MW AND CAMACHO JPM. 1996. Evidence for B chromosome drive suppression in the grasshopper Eyprepocnemis plorans. Heredity 76: 633-639.

Jesus CM, Galetti JR PM, VALENTINI SR AND MoreiraFILHO O. 2003. Molecular characterization and chromosomal location of two families of satelite DNA in Prochilodus lineatus (Pisces, Prochilodontidae), a species with B chromosomes. Genetica 118: 25-32.

Jesus CM AND MoReIRA-Filho O. 2003. Chromosomal localization of 5S and 18S rRNA genes in Prochilodus lineatus (Characiformes, Prochilodontidae). Caryologia 56: 281-287.

JONES RN. 1985. Are B chromosome selfish? In: Cavalier Smith T (Ed), The evolution of genome size. Wiley, p. 397-425.

LEVAN A, Fredga K AND SANDBERG AA. 1964. Nomenclature for centromeric position on chromosomes. Hereditas 52: 201-220

LÓPEZ-LeÓn MD, CABRERO J, CAMACHO JPM, CANO MI AND SANTOS JL. 1992. A widespread B chromosome polymorphism maintained without apparent drive. Evolution 46: 529-539.

Maistro EL, Foresti F, Oliveira C AND AlmeidA-Toledo LF. 1992. Occurrence of macro B chromosome in Astyanax scabripinnis paranae (Pisces, Characiformes, Characidae). Genetica 87: 101-106. 
Moreira-Filho O, FenOCCIO AS, PAStori MC AND Bertollo LAC. 2001. Occurrence of a metacentric macrochromosome B in different species of the genuns Astyanax (Pisces, Characidae, Tetragonopterinae). Cytologia 66: 59-64.

NUR U. 1966a. Harmful B chromosomes in a mealy bug population. Genetics 54: 1225-1238.

NuR U. 1966b. The effect of supernumerary chromosomes on the development of mealy bugs. Genetics 54: 1239-1249.

NUR U. 1977. Maintenance of a "parasitic" B chromosome in the grasshopper Melonoplus femur-rubrum. Genetics 87: 499-512.

NUR U AND BRETT BLH. 1987. Control of meiotic drive of B chromosomes in the mealy bug Pseudococcus affinis (obscurus). Genetics 115: 499-510.

NUR U AND BRETT BLH. 1988. Genotypes affecting the condensation and transmission of heterochromatic B chromosomes in the mealy bug Pseudococcus affnis. Chromosoma 96: 205-212.

OLIVEIRA C, FORESTI F AND HILLDORF AWS. 2009. Genetics of neotropical fish: from chromosomes to populations. Fish Physiol Biochem 35: 81-100

Oliveira C, Nirchio M, Granado A AND LeVy S. 2003. Karyotypic characterization of Prochilodus mariae, Semaprochilodus Kneri and Semaprochilodus laticeps (Teleostei:Prochilodontidae) from Caicara del Orinoco, Venezuela. Neotropical Ichthyology 1: 47-52.

Oliveira C, SABOya SMR, Foresti F, SENHORINI JA AND BERNARDINO G. 1997. Increased B chromosome frequency and absence of drive in the fish Prochilodus lineatus. Heredity 79: 473-476.

Östergren G. 1945. Parasitic nature of extra fragment chromosomes. Bot Notiser 2: 157-163.

PARKER JS, TAYLOR S AND AINSWORTH CC. 1982. The B chromosome system of Hypochoeris maculata. III. Variation in B chromosome transmission rates. Chromosoma 85: 229-310.

PAUls E AND BerTOLlo LAC. 1983. Evidence for a system of supranumerary chromosomes in Prochilodus scrofa Steindacher 1881 (Pisces, Prochilodontidae). Caryologia 36(4): 307-314.

PAUls E AND Bertollo LAC. 1990. Distribution of a supernumerary chromosome system and aspects of cariotipic evolution in the genus Prochilodus (Pisces, Prochilodontidae). Genetica 81: 117-123.
SALVADOR LB AND MOREIRA-FILHO O. 1992. B chromosome in Astyanax scabripinnis (Pisces, Characidae). Heredity 69: $50-56$.

Schartl M, NANda I, Schlupp I, Wilde B, Epplen JT, SCHMIDT M AND PARZEFALL J. 1995. Incorporation of subgenomic amounts of DNA as compensation for mutational load in a gynogenetic fish. Nature 373: 68-71.

SHAW MW AND HEWITT GM. 1985. The genetic control of meiotic drive acting on the $\mathrm{B}$ chromosome of Myrmeleotettix maculatus (Orthoptera: Acrididae). Heredity 54: 259-268.

SHAW MW AND HEWITT GM. 1990. B chromosomes, selfish DNA and theoretical models: where next? In: Futuyma D and Antonovics J (Eds), Oxford surveys in evolutionary biology. Oxford Univ Press, p. 197-223.

ShaW MW, HewitT GM AND ANDERSON DA. 1985. Polymorphism in the rates of meiotic drive acting on the chromosome of Myrmeleotettix maculatus. Heredity 55: 61-68.

Venere PC, Miyazawa CS And Galetti JR PM. 1999. New cases of supernumerary chromosomes in characiform fishes. Genet Mol Biol 22: 345-349.

Vicente VE, MoReira-Filho O AND CAMACHO JPM. 1996. Sex-ratio distortion associated with the presence of a B chromosome in Astyanax scabripinnis (Teleostei, Characidae). Cytogenetic Cell Genet 74: 70-75.

Voltolin TA, SENHORINI JA, Foresti F, BORTOLOZZI J AND PORTO-FORESTI F. 2011. Intraspecific crosses resulting in the first occurrence of eight and nine B chromosomes in Prochilodus lineatus (Characiformes, Prochilodontidae). Genet Mol Biol 34(2): 220-224.

Voltolin TA, Senhorini JA, Oliveira C, Foresti F, Bortolozzi J AND PORTO-Foresti F. 2009. Cytogenetic Markers in Wild Population of Curimbatá (Prochilodus lineatus) from Mogi-Guaçu River. Cytologia 74(3): 281287.

Voltolin TA, SENHORINI JA, Oliveira C, Foresti F, Bortolozzi J AND PORTO-Foresti F. 2010. Supernumerary chromosome inheritance in the curimbatá (Prochilodus lineatus) of the Mogi-Guaçu River. Hereditas 147: 127-131.

WHITE MJD. 1973. Animal cytology and evolution. Cambridge Univ Press, 961 p. 